\title{
AKIBAT HUKUM PERBEDAAN BAKU MUTU UDARA AMBIEN PARAMETER DEBU PADA PERATURAN PEMERINTAH REPUBLIK INDONESIA NOMOR 41 TAHUN 1999 TENTANG PENGENDALIAN PENCEMARAN UDARA DENGAN PERATURAN GUBERNUR JAWA TIMUR NOMOR 10 TAHUN 2009 TENTANG BAKU MUTU UDARA AMBIEN DAN EMISI SUMBER TIDAK BERGERAK
}

\author{
Beny Aziz Setiawan*, Moh. Nasichin** \\ Program Studi Ilmu Hukum Fakultas Hukum Universitas Gresik \\ * Mahasiswa Fakultas Hukum Universitas Gresik \\ **Dosen Fakultas Hukum Universitas Gresik \\ Email: Mohamadnasichin@gmail.co.id / benyrotinsulu@gmail.com
}

\begin{abstract}
ABSTRAK
Baku mutu udara ambien ditetapkan pemerintah untuk mencegah dan mengontrol penurunan mutu udara ambien akibat pencemaran. Terdapat perbedaan baku mutu udara ambien dalam peraturan gubernur provinsi Jawa Timur menggunakan parameter debu/TSP dengan nilai batas $260 \mu \mathrm{g} / \mathrm{Nm}^{3}$, sedangakan baku mutu nasional parameter debu/TSP dengan nilai batas 230 $\mu \mathrm{g} / \mathrm{Nm}^{3}$. Debu/TSP dalam baku mutu udara ambien Jawa Timur tidak sesuai dengan penerapan asas perundang-undangan. Peraturan daerah yang bertentangan dengan peraturan pemerintah dapat dibatalkan oleh pemerintah, yang mengandung pengertian baku mutu udara ambien Jawa Timur tersebut tetap sah, namun untuk baku mutu parameter debu/TSP Jawa Timur tidak memiliki kekuatan hukum tetap. Pemerintah provinsi Jawa Timur dalam menentukan status mutu udara ambien untuk baku mutu parameter debu/TSP harus mengacu pada baku mutu udara ambien nasional.
\end{abstract}

Kata kunci : Udara ambien; Paraneter debu/TSP; Baku mutu.

\section{ABSTRACT}

Ambient air quality standards are determined by the government to prevent and control the deterioration in the quality of ambient air due to pollution. There are differences in ambient air quality standards in the governor regulation of East Java province using the parameter of dust / TSP with a limit value of $260 \mu \mathrm{g} /$ $\mathrm{Nm3}$, while the national quality standard parameter is dust / TSP with a limit value of $230 \mu \mathrm{g} / \mathrm{Nm3}$. Dust / TSP in the East Java ambient air quality standard 
is not in accordance with the application of statutory principles. Regional regulations that are contrary to government regulations can be canceled by the government, which contain the East Java ambient air quality standard is still valid, but for the East Java TSP dust / TSP quality standards do not have permanent legal force. The provincial government of East Java in determining ambient air quality status for dust / TSP parameter quality standards must refer to national ambient air quality standards.

Keywords: Ambient air; dust / TSP paraneter; quality standard.

\section{A. PENDAHULUAN}

Lingkungan hidup yang sehat merupakan aspek yang sangant penting bagi kelangsungan hidup bangsa indonesia. Kerusakan lingkungan akan sangat berpengaruh pada kulitas hidup masyarakat. Lingkungan yang bersih dan sehat akan membantu masyarakat tumbuh dan berkembang dengan baik. Mendapatkan lingkungan hidup yang baik adalah hak bagi seluruh warga negara Indonesia seperti yang telah tercantum pada Pasal $28 \mathrm{H}$ ayat 1 UUD 1945 yaitu, "Setiap orang berhak hidup sejahtera lahir batin, bertempat tinggal dan mendapatkan lingkungan hidup yang baik dan sehat serta berhak memperoleh pelayanan kesehatan". Dengan demikian pemerintah wajib menjamin dan menjaga lingkungan hidup tetap baik dan tidak tercemar.

Dalam rangka untuk menjaga lingkungan hidup dari pencemaran yang dilakukan dari berbagai sektor, pemerintah membuat UndangUndang Nomor 4 Tahun 1982 tentang Ketentuan-Ketentuan Pokok Pengelolaan Lingkungan Hidup yang kemudian diganti dengan UndangUndang Nomor 23 tahun 1997 tentang Pengelolaan Lingkungan Hidup yang diubah lagi dengan
Undang-Undang Nomor 32 Tahun 2009 tentang Perlindungan dan Pengelolaan Lingkungan Hidup.

Salah satu komponen lingkungan yang sangat penting bagi kehidupan adalah udara. Udara merupakan kebutuhan seluruh mahluk hidup untuk bernafas, seseorang masih bisa bertahan beberapa hari dengan tanpa makanan dan minuman, tapi tidak dengan udara, mahluk hidup akan mengalami kematian bila dipisahkan dengan udara.

Negara telah menetapkan baku mutu nasional untuk mencegah dan mengontrol penurunan mutu udara ambien akibat pencemaran zat-zat yang masuk dalam Peraturan Pemerintah Republik Iindonesia Nomor 41 Tahun 1999 tentang Pengendalian Pencemaran Udara yang didalamnya mengatur standart mutu udara ambien nasional. Tidak hanya itu, Peraturan Pemerinah Republik Indonesia Nomor 41 Tahun 1999 ini juga mengatur pengendalian pencemaran udara dari sumber pencemarannya seperti yang disebutkan dalam Pasal 2 yaitu :

Pengendalian pencemaran udara meliputi pengendalian dari usaha dan/atau kegiatan sumber bergerak, sumber bergerak spesifik, 
sumber tidak bergerak, dan sumber tidak bergerak spesifik yang dilakukan dengan upaya pengendalian sumber emisi dan/atau sumber gangguan yang bertujuan untuk mencegah turunnya udara ambien.

Dalam Peraturan Pemerintah Republik Indonesia Nomor 41 Tahun 1999 tentang Pengendalian Pencemaran Udara juga memperbolehkan Gubernur membuat baku mutu udara ambien sendiri di wilayahnya, seperti yang tertulis dalam Pasal 5 :

(1) Baku mutu udara ambien daerah ditetapkan berdasarkan pertimbangan status mutu udara ambien di daerah yang bersangkutan

(2) Gubernur menetapkan baku mutu udara ambien daerah sebagaimana dimaksud pada ayat (1) berdasarkan baku mutu udara ambien nasional.

Untuk peraturan tentang mutu udara ambien di Provinsi Jawa timur, Gubernur Jawa Timur telah menetapkan Peraturan Gubernur Jawa timur Nomor 10 Tahun 2009 tentang Baku Mutu Udara Ambien Dan Emisi Sumber Tidak Bergerak. Ada perbedaan baku mutu udara ambien nasional dengan baku mutu udara ambien yang di tetapkan oleh Gubernur Jawa Timur pada parameter debu/TSP. Dalam baku mutu udara ambien nasional parameter debu/TSP memiliki nilai batas $230 \mu \mathrm{g} / \mathrm{Nm}^{3}$, namum di dalam baku mutu udara ambien regional Jawa Timur untuk baku mutu udara ambien parameter debu/TSP nilainya $0,26 \mathrm{mg} / \mathrm{Nm}^{3}$. Adapun tujuan penulisan ini adalah untuk mengetahui asas-asas yang dilanggar dan akibat hukum yang terjadi terhadap perbedaan baku mutu udara ambien parameter debu/TSP. Berdasarkan latar belakang dan tujuan penelitian yang telah diuraian diatas, maka penulis akan membahasnya lebih lanjut dalam penulisan ini dengan judul "Perbedaan Baku Mutu Udara Ambien Parameter Debu".

\section{B. METODE PENELITIAN}

Penelitian ini akan disusun menggunakan metode penelitian yuridis normatif, yaitu penelitian yang difokuskan untuk mengkaji peraturan perundang-undangan serta menelaah penerapan kaidah-kaidah atau norma-norma dalam hukum, asas-asas hukum yang berkaitan dengan pokok permasalahan yang telah dirumuskan dalam penelitian ini. Dalam penelitian ini penulis menggunakan pendekatan konseptual, pendekatan undangundang, dan pendekatan komparatif.

\section{PEMBAHASAN}

1. Parameter dan Baku Mutu Partikulat Debu Udara Ambien Pengertian udara ambien menurut Pasal 1 ayat (4) Peraturan Pemerintah Republik Indonesia Nomor 41 Tahun 1999 tentang Pengendalian Pencemaran Udara, (disingkat PPRI Nomor 41 Tahun 1999) yaitu : Udara ambien adalah udara bebas dipermukaan bumi pada lapisan troposfir yang berada di dalam wilayah yuridiksi Republik Indonesia yang dibutuhkan dan mempengaruhi kesehatan manusia, makhluk hidup dan unsur lingkungan hidup lainnya. Bahasa sederhananya, udara ambien adalah udara yang kita hirup sehari-hari.

Dalam Pasal 1 ayat (5) PPRI Nomor 41 Tahun 1999 dijelaskan 
yang dimaksud mutu udara ambien adalah kadar zat, energy, dan/atau komponen lain yang ada di udara bebas. Untuk pengertian pencemaran udara menurut Pasal 1 ayat (1) PPRI Nomor 41 Tahun 1999 adalah masuknya zat, energi, dan/atau komponen lain ke dalam udara ambien oleh kegiatan manusia, sehingga mutu udara ambien turun sampai ke tingkat tertentu yang menyebabkan udara ambien tidak dapat memenuhi fungsinya.

Sedangkan pengertian baku mutu udara ambien dalam Pasal 1 ayat (7) PPRI Nomor 41 Tahun 1999 adalah ukuran batas atau kadar zat, energi, dan/atau komponen yang ada atau yang seharusnya ada dan atau unsur pencemar yang ditenggang keberadaanya dalam udara ambien. Penentuan baku mutu udara ambien sangatlah penting karena digunakan sebagai tolak ukur atau penentu status mutu udara di suatu wilayah, dan juga sebagai pencegah terjadinya pencemaran udara.

Hal ini dipertegas dalam Pasal 3 PPRI Nomor 41 Tahun 1999 yang menyatakan bahwa, perlindungan mutu udara ambien didasarkan pada baku mutu udara ambien, status mutu udara ambien, baku mutu emisi, ambang batas emisi gas buang, baku tingkat gangguan, ambang batas kebisingan dan indeks standar pencemaran udara. Juga dalam Pasal 4 ayat (1) yang menyatakan : Baku mutu udara ambien nasional ditetapkan sebagai batas maksimum mutu udara ambien untuk mencegah terjadinya pencemaran udara, sebagaimana terlampir dalam Peraturan Pemerintah ini.

PPRI Nomor 41 Tahun 1999 juga memperbolehkan daerah provinsi menentukan baku mutu udara ambiennya di wilayahnya sendiri. Hal ini disebutkan dalam Pasal 5 PPRI Nomor 41 Tahun 1999 yang pada intinya gubernur provinsi Jawa Timur dapat menetapkan baku mutu di wilayah yuridiksinya dengan catatan baku mutu tersebut harus mengacu pada baku mutu nasional, paling tidak baku mutu tersebut harus sama atau lebih ketat dari baku mutu nasional, dan apabila ada baku mutu udara yang belum diatur oleh gubernur provinsi Jawa Timur maka secara otomatis berlaku baku mutu udara ambien nasional.

Baku mutu partikulat debu yang diatur dalam baku mutu udara ambien Peraturan Gubernur Jawa Timur Nomor 10 Tahun 2009 tentang Baku Mutu Udara Ambien dan Emisi Sumber Tidak Bergerak hanya parameter debu/TSP dengan waktu pemaparan 24 jam dan angka baku mutu $0,26 \mathrm{mg} / \mathrm{Nm}^{3}$ yang bila dikonversikan ke satuan $\mu \mathrm{g} / \mathrm{Nm}^{3}$ menjadi $260 \mu \mathrm{g} / \mathrm{Nm}^{3}$, angka ini tentunya lebih besar dibandingkan baku mutu TSP (debu) nasional yang hanya $230 \mu \mathrm{g} / \mathrm{Nm}^{3}$.

Partikulat debu merupakan salah satu zat pencemar utama. Menurut, "Roger W. Findley dan Daniel A. Farber mengelompokkan lima bahan pencemar udara (yang) utama: Partikel, Karbon Monoksida (CO), Sulfur Oksida $\left(\mathrm{SO}_{\mathrm{X}}\right)$, Nitrogen Oksida $\left(\mathrm{NO}_{\mathrm{X}}\right)$, Hidrokarbon $(\mathrm{HC}) .{ }^{.1}$

Partikulat mengandung berbagai unsur (debu, aerosol, timah hitam, asap, asbestos, minyak, garam

\footnotetext{
1 Suparto Wijoyo, Refleksi Mata Rantai pengaturan Hukum Pengelolaan Lingkungan Secara Terpadu (Studi Kasus Pencemaran Udara), Cet. I, Airlangga University Press, Surabaya, 2005, h. 24.
} 
sulfat). "Pencemaran udara karena partikel debu biasanya menyebabkan penyakit pernapasan kronis seperti bronchitis khronis, emfisma paru, asma bronchial dan bahkan kanker paru." "2

\begin{tabular}{lrr}
\multicolumn{2}{c}{ Diterangkan dalam } & Undang- \\
undang & Perlindungan & dan \\
Pengelolaan & Lingkungan & Hidup
\end{tabular} (yang pada penulisan ini disingkat UUPPLH) Pasal 13 ayat (3) Nomor 32 Tahu 2009 pada intinya "Adapun pelaksanaan pengendalian pencemaran dan/atau kerusakan lingkungan hidup dilaksanakan oleh pemerintah, pemerintah daerah, dan penanggung jawab usaha, dan/atau kegiatan sesuai dengan kewenangan, peran, dan tanggung jawab masingmasing." 3

"Salah satu otoritas pemerintah dalam rangka perlindungan dan pengelolaan lingkungan hidup adalah menerapkan izin lingkungan (environmental licence)." "“...izin merupakan alat pemerintah yang bersifat yuridis preventif, dan digunakan sebagai instrument administrasi untuk mengendalikan perilaku masyarakat." "Pengelolaan lingkungan hidup hanya dapat berhasil menunjang pembangunan berkelanjutan, apabila administrasi pemerintahan berfungsi secara efektif dan terpadu." 6

\footnotetext{
2 Moestikahadi Soedomo, Pencemaran Udara (Kumpulan Karya Ilmiah), ITB, Bandung, 2001, h. 7.

3 Yunus Wahid, Pengantar

Hukum Lingkungan, Edisi Kedua, Cet 1, Kencana, Jakarta, 2018, h. 183.

4 Helmi, Hukum Perizinan Lingkungan Hidup, Cetakan Pertama, Sinar Grafika, Jakarta, 2012, h. 26.

${ }^{5}$ Ibid, h. 28.

${ }^{6}$ Ibid.
}

Salah satu syarat untuk mendapatkan izin lingkungan adalah dengan memiliki Amdal atau UKLUPL, tergantung pada jenis perusahaannya. Pengertian Amdal dijelaskan dalam Pasal 1 ayat (11) Undang-undang Nomor 32 Tahun 2009 tentang Perlindungan dan Pengelolaan Lingkungan Hidup yang selanjutnya disebut UUPPLH bahwa, Analisis mengenai dampak lingkungan, yang selanjutnya disebut amdal, adalah kajian mengenai dampak penting suatu usaha dan/atau kegiatan yang direncanakan pada lingkungan hidup yang diperlukan bagi proses pengambilan keputusan tentang penyelenggaraan usaha dan/atau kegiatan.

Untuk

UKL-UPL pengertiannya tercantum dalam Pasal 1 ayat (12) UUPPLH yaitu, Upaya pengelolaan lingkungan hidup dan upaya pemantauan lingkungan hidup, yang selanjutnya disebut UKL-UPL, adalah pengelolaan dan pemantauan terhadap usaha dan/atau kegiatan yang tidak berdampak penting terhadap lingkungan hidup yang diperlukan bagi proses pengambilan keputusan tentang penyelenggaraan usaha dan/atau kegiatan.

Dijelaskan dalam Pasal 47 ayat (2) Peraturan Pemerintah Nomor 27 Tahun 2012 tentang Izin Lingkungan bahwa, penerbitan izin lingkungan diterbitkan bersamaan dengan diterbitkannya keputusan kelayakan lingkungan hidup atau rekomendasi UKL-UPL.

Dijelaskan dalam Pasal 32 ayat (1) Peraturan Pemerintah Nomor 27 Tahun 2012 tentang Izin Lingkungan bahwa, Menteri, gubernur, atau bupati/walikota berdasarkan rekomendasi penilaian atau penilaian 
akhir dari Komisi Penilai Amdal sebagaimana dimaksud dalam Pasal 29 atau Pasal 30, menetapkan keputusan kelayakan atau ketidak layakan lingkungan hidup.

Sedangkan untuk rekomendasi UKL-UPL diatur dalam Pasal 37 Peraturan Pemerintah Nomor 27 Tahun 2012 tentang Izin Lingkungan yaitu:

(1) Berdasarkan pemeriksaan sebagaimana dimaksud dalam Pasal 36 ayat (4), Menteri, gubernur, atau bupati/walikota menerbitkan Rekomendasi UKL-UPL.

(2) Rekomendasi sebagaimana dimaksud pada ayat (1) dapat berupa:
a. Persetujuan; atau
b. Penolakan.

Pejabat yang berwenang dalam pemeriksaan dan penerbitan rekomendasi UKL-UPL diatur dalam Pasal 40 Peraturan Pemerintah Nomor 27 Tahun 2012 tentang Izin Lingkungan yang mengatakan bahwa, pemeriksaan UKL-UPL dan penerbitan Rekomendasi UKL-UPL sebagaimana dimaksud dalam Pasal 36 dan Pasal 37 dapat dilakukan oleh:

(1) Pejabat yang ditunjuk oleh menteri;

(2) Kepala instansi lingkungan hidup provinsi; atau

(3) Kepala instansi lingkungan hidup Kabupaten/Kota.

Adapun pihak yang berwenang dalam menerbitkan izin lingkungan adalah menteri, gubernur, bupati/walikota. Dijelaskan dalam Pasal 47 ayat (1) Peraturan Pemerintah Nomor 27 Tahun 2012 tentang Izin Lingkungan yaitu, izin lingkungan diterbitkan oleh: a. Menteri, untuk Keputusan Kelayakan Lingkungan Hidup atau rekomendasi UKL-UPL yang diterbitkan oleh Menteri;

b. Gubernur, untuk untuk Keputusan Kelayakan Lingkungan Hidup atau rekomendasi UKL-UPL yang diterbitkan oleh gubernur; dan

c. Bupati/walikota, untuk Keputusan Kelayakan Lingkungan Hidup atau rekomendasi UKL-UPL yang diterbitkan oleh bupati/walikota.

Pembentukan Komisi Penilai Amdal dilakukan oleh Menteri, gubernur, atau bupati/walikota sesuai dengan kewenangannya. Komisi Penilai Amdal terdiri atas:

a. Komisi Penilai Amdal Pusat;

b. Komisi Penilai Amdal provinsi; dan

c. Komisi Penilai Amdal kabupate/kota.

\section{Asas-asas Hukum}

asas hukum merupakan salah satu dasar jang dijadikan pertimbangan dalam mengambil keputusan. "Keberadaan asas-asas hukum atau perundang-undangan yang telah dikemukakan bertujuan untuk pertama, pembentukan undang-undang, kedua, pelaksanaan undang-undang guna menyelesaikan konflik antara peraturan perundangundangan atau dengannorma hukum lainnya."7

Dalam perundang-undangan terdapat beberapa asas, diantaranya yaitu asas undang-undang tidak belaku surut (non retro active) Asas undang-undang tidak belaku surut (non retro active) yang artinya, "undang-undang hanya mengikat untuk masa mendatang dan tidak

${ }^{7}$ Umar Said Sugiarto, Pengantar Hukum Indonesia, Cetakan Pertama, Sinar Grafika, Jakarta, 2013, h. 65. 
mempunyai kekuatan yang berlaku surut")." Kemudian asas undangundang tidak dapat diganggu gugat (onschendbaar) Asas ini mempunyai arti "bahwa undang-undang tidak dapat diuji atau dinilai atau diteliti oleh siapapun apabila isinya bertentangan dengan UndangUndang Dasar. Dengan diamandemenya UUD 1945 maka Pasal 95 UUDS 1950 tidak berlaku." Asas yang selanjutnya yaitu asas undang-undang yang lebih tinggi mengesampingkan undangundang yang lebih rendah (lex superiori derogat lex inferiori) asas ini mengandung arti "Apabila ada dua peraturan perundang-undangan yang tidak sederajat mengatur objek yang sama dan saling bertentangan, maka hakim harus menerapkan atau menggunakan undang-undang yang lebih tinggi sebagai sebagai dasar putusan hakim, dan menyatakan undang-undang yang lebih rendah tidak mempunyai kekuatan hukum mengikat."10 Kemudian ada asas undang-undang yang bersifat khusus mengesampingkan undang-undang yang bersifat umum (lex specialis derogat lex generalis), undangundang yang berlaku belakangan membatalkan undang-undang yang terdahulu (lex posteriori derogat lex priori).

Penyelenggaraan pemerintahan daerah didasarkan pada tiga asas, yaitu asas desentralisasi, asas dekonsentrasi, dan asas tugas pembantuan. Ketiga asas tersebut

${ }^{8}$ Christine S.T. Kansil, Pengantar Ilmu Hukum Jilid I, Cetakan Sebelas, Balai Pustaka, Jakarta, 2000, h. 155.

${ }^{9}$ Umar Said Sugiarto, Op.Cit., h. 53.

${ }^{10}$ Ibid, h. 62. tertuang dalam Undang-undang Nomor 32 Tahun 2004 tentang Pemerintahan Daerah. Pengertian asas disentralisasi dalam Pasal 1 angka 7 Undang-undang Nomor 32 Tahun 2004 tentang Pemerintahan Daerah adalah penyerahan wewenang pemerintahan oleh pemerintah kepada daerah otonom untuk mengatur dan mengurus urusan pemerintahan dalam sistem Negara Kesatuan Republik Indonesia. Menurut Amrah Muslimin "desentralisasi adalah perlimpahan wewenang pada badan-badan dan golongan-golongan dalam masyarakat dalam daerah tertentu untuk mengurus rumah tangganya sendiri."11

Asas dekonsentrasi dalam Undang-undang Nomor 32 Tahun 2004 tentang Pemerintahan Daerah Pasal 1 angka 8 adalah pelimpahan wewenang pemerintahan kepada gubernur sebagai wakil pemerintah dan/atau kepada instansi vertikal di wilayah tertentu. Arti asas dekonsentrasi menurut Amrah Muslimin adalah "pelimpahan sebagian dari kewenangan pemerintah pusat pada alat-alat pemerintah pusat yang ada di daerah."12

Asas tugas pembantuan dalam Undang-undang Nomor 32 Tahun 2004 tentang Pemerintahan Daerah Pasal 1 angka 9 adalah penugasan dari pemerintah kepada daerah dan/atau desa dari pemerintah provinsi kepada Kabupaten/Kota dan/atau desa serta dari pemerintah Kabupaten/Kota kepada desa untuk

11 Amrah Muslimin, Aspek-aspek Hukum Otonomi Daerah, Alumni, Bandung, 1986, h. 5.

12 Ibid, h. 4. 
melakukan tugas tertentu. Menurtu Ni'matul Huda, “tugas pembantuan ialah tugas ikut melaksanakan urusan urusan pemerintah pusat atau pemerintah lokal yang berhak mengatur dan mengurus rumah tangga tingkat atasannya." 13

\section{Alasan Pembatalan Peraturan Daerah}

"Pembatalan Perda yang dilakukan oleh pemerintah merupakan bentuk pengawasan yang bersifat hierarkhis sebagai konsekuensi logis dari asas/prinsip negara kesatuan sebagaimana diatur dalam ketentuan Pasal 1 ayat (1) juncto Pasal 18 ayat (1) UUD Negara Republik Indonesia Tahun 1945". ${ }^{14}$

Ada dua lembaga yang berwenang dalam membatalka Peraturan Daerah, Yaitu pemerintah dan Mahkamah Agung.

"Pasal 145 ayat (2) dan ayat (3) Undang-undang Nomor 32 tahun 2004 tentang Pemerintahan Daerah mengamanatkan bahwa Perda yang bertentangan dengan kepentingan umum dan/atau peraturan perundangundangan yang lebih tinggi dapat dibatalkan oleh pemerintah dengan Peraturan Presiden". 15

Dalam rangka pengawasan terhadap Perda dirumuskan tentang pembatalan Perda dalam Pasal 251 Undang-undang Nomor 23 Tahun 2014 tentang Pemerintahan Daerah sebagai berikut: ${ }^{16}$

13 Ni'matul Huda, Hukum Tata Negara Indonesia, PT RajaGrafindo Persada, Jakarta, 2005, h. 312.

14 Sukardi, Pengawasan Dan Pembatalan Peraturan Daerah, Cetakan Pertama, Genta Publishing, Yogyakarta, 2016, h. 87.

${ }^{15}$ Ibid.
${ }^{16}$ Ibid.
(1) Perda Provinsi dan peraturan gubernur yang bertentangan dengan ketentuan peraturan perundang-undangan yang lebih tinggi, kepentingan umum, dan/atau kesusilaan dibatalkan oleh menteri

(4) Pembatalan Perda Provinsi dan peraturan gubernur sebagaimana dimaksud paada ayat (1) ditetapkan dengan keputusan menteri dan pembatalan Perda Kabupaten/Kota dan peraturan bupati/wali kota sebagaimana dimaksud pada ayat (2) ditetapkan dengan keputusan gubernur sebagai wakil Pemerintah Pusat.

Ketentuan Pasal 24A ayat (1) UUD Negara Republik Indonesia Tahun Tahun 1945 menyatakan: Mahkamah Agung berwenang mengadili pada tingkat kasasi, menguji peraturan perundangundangan di bawah undang-undang terhadap undang-undang, dan mempunyai wewenang lainnya yang diberikan oleh undang-undang.

Alasan pembatalan Perda karena bertentangan dengan peraturan perundang-undangan yang lebih tinggi, untuk hierarkinya dapat dilihat dalam Pasal 2 Ketetapan MPR Nomor III/MPR/2000 yang menentukan hierarki peraturan perundang-undangan sebagai berikut:

1. Undang-Undang Dasar 1945;

2. Ketetapan

Majelis

Permusyawaratan

Rakyat Republik Indonesia;

3. Undang-Undang;

4. Peraturan Pemerintah Pengganti Undang-Undang (Perpu);

5. Peraturan Pemerintah;

6. Peraturan Presiden; dan

7. Peraturan Daerah. 
Hierarki peraturan perundangundangan juga dapat dilihat dalam Pasal 7 Undang-undang Nomor 10 Tahun 2004 tentang Pembentukan Peraturan Perundang-undangan juga menyatakan tentang hierarki Peraturan Perundang-undangan sebagai berikut:

a. Undang-Undang Dasar Negara Republik Indonesia Tahun 1945;

b. Undang-undang/Peraturan Pemerintah Pengganti Undangundang;

c. Peraturan Pemerintah;

d. Peraturan Presiden; dan

e. Peraturan Daerah.

\section{Akibat Hukum Pembatalan}

\section{Peraturan Daerah}

Dengan dibatalkan suatu Perda, maka berarti: ${ }^{17}$

1. Perda tersebut, sudah tidak mempunyai kedayagunaan, namun Perda tersebut dipandang masih tetap ada selama belum dicabut; dan

2. Perda tersebut tidak boleh dibuatkan peraturan pengganti yang berkenaan dengan substansi isi materinya sebelum perda tersebut dinyatakan dicabut.

Pengertian batal disini disamakan dengan pengertian "tidak berlaku" sebagaimana dimaksud dalam ketentuan Pasal 11 ayat (3) Undang-undang Nomor 4 Tahun 2004 juncto Pasal 20 ayat (3) Undang-undang Nomor 48 tahun 2009 dan pengertian "tidak sah" yang diikuti dengan kata "tidak mempunyai kekuatan hukum mengikat" sebagaimana dimaksud

17 Minolah, Tinjauan Yuridis

Terhadap PembatalanPeraturan Daerah provinsi Di Indonesia, Vol. 8, No. 1, Fakultas Hukum, Universitas Islam Bandung, Bandung, 2011,h. 14. dalam Pasal 31 ayat (4) Undangundang Nomor 14 Tahun 1985 juncto Undang-undang Nomor 3 Tahun 2009. ${ }^{18}$

Sementara mengenai konsep bentuk-bentuk kebatalan, Philipus M. Hadjon menjelaskan: ${ }^{19}$

Keputusan yang tidak sah dapat berakibat "neitigheid van rechtswege" (batal karena hukum), "nietig" (batal) atau "vernietigbaar" (dapat dibatalkan).

"Nietig" berarti bahwa bagi hukum perbuatan yang dilakukan dianggap tidak ada. Konsekuensinya, bagi hukum akibat perbuatan itu dianggap tidak pernah ada.

"Vernietigbaar" berarti: bagi hukum perbuatan yang dilakukan dan akibatnya dianggap ada sampai waktu pembatalan oleh hakim atau badan pemerintahan lain yang kompeten.

"Neitigheid van rechtswege" artinya bagi hukum akibat suatu perbuatan dianggap tidak ada tanpa perlu adanya suatu keputusan yang membatalkan perbuatan tersebut.

"Konsep "dapat dibatalkan" bagi perda yang bertentangan dengan kepentingan umum atau peraturan perundang-undangan yang lebih tinggi sesuai dengan asas praesumptio iustae causa dalam

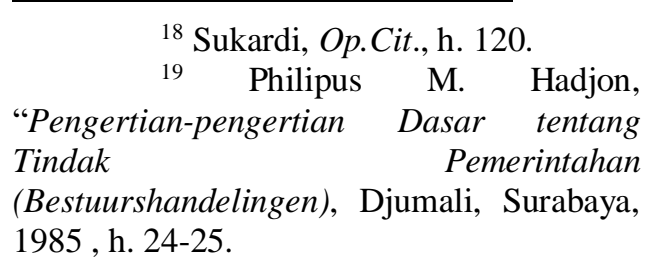


Hukum Administrasi yang berarti bahwa peraturan tetap dianggap sah sampai dapat dibuktikan sebaliknya. ${ }^{20}$

Menurut E. Utrecht suatu putusan yang dapat dibatalkan (vernietigbaar) berarti :

Bagi hukum perbuatan yang dilakukan dan akibatnya dianggap ada sampai waktu pembatalan oleh hakim atau oleh suatu badan pemerintah lain yang berkompeten (pembatalan itu diadakan karena perbuatan tersebut mengandung susatu kekurangan). Bagi hukum, perbuatan itu ada sampai waktu pembatalannya dan oleh sebab itu segala akibat yang ditimbulkan antara waktu mengadakannya sampai waktu pembatalannya, menjadi sah (terkecuali dalam hal undang-undang menyebut beberapa bagian akibat itu tidak sah). Setelah pembatalan maka perbuatan itu tidak ada dan-bila mungkin-diusahakan supaya akibat yang telah terjadi itu semuanya atau sebagiannya hapus. ${ }^{21}$

\section{Akibat Hukum Perbedaan Baku Mutu Parameter Debu/TSP}

Tujuan perlindungan dan pengelolaan lingkungan hidup bertujuan untuk menjaga kelayakan lingkungan hidup. Salah satu langkah pemerintah dalam menjaga kelayakan lingkungan hidup adalah dengan menerapkan izin lingkungan yang diatur dalam Undang-undang Nomor 32 Tahun 2009 tentang Perlindungan dan Pengelolaan

${ }^{20}$ Sukardi, Op.Cit., h. 122.

21 E. Utrecht, Pengantar Hukum Administrasi Negara Indonesia, Cet 4, Fakultas Hukum dan Pengetahuan Masyarakat Universitas Negeri Pajajaran, Bandung, 1960, h. 78.
Lingkungan Hidup, atau bisa disingkat UUPPLH.

Izin lingkungan merupakan prasyarat untuk izin usaha dan/atau kegiatan untuk melakukan usaha dan/atau kegiatan. Syarat untuk mendapatkan izin lingkungan adalah setiap usaha dan/atau kegiatan wajib memiliki Amdal atau UKL-UPL, dijelaskan dalam UUPPLH Pasal 22 dan Pasal 34.

Gubernur provinsi Jawa Timur, Komisi Penilai Amdal, dan/atau kepala instansi lingkungan hidup provinsi Jawa Timur berwenang menilai Amdal dan/atau UKL-UPL, memutuskan kelayakan atau ketidak layakan lingkungan hidup, menerbitkan rekomendasi UKL-UPL untuk usaha dan/atau kegiatan yang wilayahnya melibatkan dua Kabupaten/Kota atau lebih dalam wilayah pemerintahan provinsi Jawa Timur.

Bupati/walikota di provinsi Jawa Timur, Komisi Penilai Amdal Kabupaten/Kota, dan/atau kepala instansi lingkungan hidup Kabupaten/Kota di provinsi Jawa Timur berwenang menilai Amdal dan/atau UKL-UPL, memutuskan kelayakan atau ketidak layakan lingkungan hidup,menerbitkan rekomendasi UKL-UPL untuk usaha dan/atau kegiatan yang hanya melibatkan satu wilayah Kabupaten/Kota.

Amdal dan UKL-UPL ditujukan salah satunya untuk mengetahuai dan menilai dampak dari adanya usaha dan/atau kegiatan terhadap mutu lingkungan, diantaranya adalah mutu udara ambien. Salah satu syarat untuk mendapatkan nilai kelayakan lingkungan hidup dalam Amdal dan 
mendapatkan rekomendasi UKLUPL adalah setiap usaha dan/atau kegiatan harus memenuhi mutu udara ambien.

Status mutu udara ambien didapatkan dengan cara melakukan inventarisasi dan/atau penelitian pada mutu udara ambien. Hal ini dijelaskan dalam PPRI Nomor 41 Tahun 1999 Pasal 6 ayat (1). Status mutu udara ditentukan dengan mengacu pada baku mutu udara ambien, apabila mutu udara ambien melebihi baku mutu maka ditetapkan bahwa daerah tersebut udaranya telah tercemar. Hal ini ditegaskan dalam Pasal 7 ayat (1) PPRI Nomor 41 Tahun 1999. Baku mutu udara ambien nasional diatur dalam PPRI Nomor 41 Tahun 1999, sedangkan bamu mutu udara ambien Jawa Timur diatur dalam Peraturan Gubernur Jawa Timur Nomor 10 Tahun 2009.

Setiap usaha dan/atau kegiatan wajib mentaati baku mutu udara ambien, seperti yang telah dijelaskan dalam Pasal 21 huruf a PPRI Nomor 41 Tahun 1999 bahwa, setiap orang yang melakukan usaha dan/atau kegiatan yang mengeluarkan emisi dan/atau baku tingkat gangguan ke udara ambien wajib menaati baku mutu udara ambien, baku mutu emisi, dan/atau baku tingkat gangguan yang ditetapkan untuk usaha dan/atau kegiatan yang dilakukannya.

Dijelaskan juga dalam Peraturan Gubernur Jawa Timur Nomor 10 Tahun 2009 Pasal 2 ayat (2) bahwa, Industri atau jenis kegiatan usaha lainnya sebagaimana dimaksud pada ayat (1), baku mutu udara ambiennya ditetapkan sebagaimana tersebut dalam lampiran II.

Jadi untuk setiap usaha dan/atau kegiatan di wilayah Jawa Timur dalam menentukan status mutu udara ambiennya mengacu pada baku mutu udara ambien provinsi Jawa Timur. Namun ada perbedaan penetapan parameter dan nilai baku mutu pada baku mutu partikulat/debu dalam baku mutu udara ambien di Peraturan Gubernur Jawa Timur Nomor 10 Tahun 2009 dengan baku mutu udara ambien pada PPRI Nomor 41 Tahun 1999. Baku mutu partikulat debu yang diatur dalam baku mutu udara ambien Peraturan Gubernur Jawa Timur Nomor 10 Tahun 2009 hanya parameter debu/tsp dengan waktu pemaparan 24 jam dan angka baku mutu $0,26 \mathrm{mg} / \mathrm{Nm}^{3}$ yang bila dikonversikan ke satuan $\mu \mathrm{g} / \mathrm{Nm}^{3}$ menjadi $260 \mu \mathrm{g} / \mathrm{Nm}^{3}$, angka ini tentunya lebih besar dibandingkan baku mutu debu/TSP nasional yang hanya $230 \mu \mathrm{g} / \mathrm{Nm}^{3}$. Hal ini tentunya bertentangan dengan PPRI Nomor 41 Tahun 1999 pada Pasal 5 ayat (3) yang menuturkan bahwa baku mutu udara ambien daerah sebagaimana dimaksud pada ayat (1) ditetapkan dengan ketentuan sama dengan atau lebih ketat dari baku mutu udara ambien nasional.

Hemat penulis Seusai dengan Pasal 145 ayat (2) Undang-undang Nomor 32 Tahun 2004 juncto Pasal 251 ayat (1) Undang-undang Nomor 23 Tahun 2014 yang menyatakan bahwa, perda sebagaimana dimaksud pada ayat (1) yang bertentangan dengan kepentingan umum dan/atau peraturan perundang-undangan yang lebih tinggi dapat dibatalkan oleh Pemerintah. 
Dalam konsep yang berlaku adalah sifat dapat dibatalkan (vernietigbaar), yang berarti peraturan tersebut dianggap tetap sah sampai waktu pembatalan oleh hakim atau oleh suatu badan pemerintah lain yang berkompeten. Namun baku mutu parameter debu/TSP bertentangan atau tidak sesuai dengan Asas lex superiori derogat lex inferiori. Yang mengakibatkan baku mutu udara ambien parameter debu/TSP dalam Peraturan Gubernur Jawa Timur Nomor 10 Tahun 2009 tidak memiliki kekuatan hukum tetap.

Hemat penulis, akibat hukum bagi baku mutu udara ambien parameter debu/TSP dalam Peraturan Gubernur Jawa Timur Nomor 10 Tahun 2009 yang bertentangan dengan Peraturan Pemerintah Republik Indonesia No. 41 Tahun 1999 yaitu, Peraturan Gubernur Jawa Timur Nomor 10 Tahun 2009 tetap berlaku, namun untuk baku mutu udara ambien parameter debu/TSP pemerintah provinsi Jawa Timur dan pemerintah Kabupaten/Kota di Jawa Timur harus mengacu pada baku mutu udara ambien parameter debu/TSP dalam PPRI Nomor 41 Tahun 1999, karena baku mutu udara ambien parameter debu/TSP dalam Peraturan Gubernur Jawa Timur Nomor 10 Tahun 2009 tidak memiliki kekuatan hukum tetap.

- Dengan kata lain, gubernur provinsi Jawa Timur, Komisi Penilai Amdal, dan/atau kepala instansi lingkungan hidup provinsi Jawa Timur dan/atau bupati/walikota di provinsi Jawa Timur, Komisi Penilai Amdal Kabupaten/Kota, dan/atau kepala instansi lingkungan hidup Kabupaten/Kota di provinsi Jawa
Timur untuk baku mutu udara ambien parameter debu/TSP harus menggunakan baku mutu udara ambien parameter debu/tsp PPRI Nomor 41 Tahun 1999 sebagai acuan.

\section{KESIMPULAN}

Angka baku mutu parameter debu/TSP dalam udara ambien pada Peraturan Gubernur Jawa Timur Nomor 10 Tahun 2009 bertentangan atau tidak sesuai dengan Asas lex superiori derogat lex inferiori. Yang menyebabkan baku mutu parameter debu/TSP udara ambien pemerintah provinsi Jawa Timur tidak memiliki kekuatan hukum tetap. Sehingga Gubernur provinsi Jawa Timur, Komisi Penilai Amdal, dan/atau kepala instansi lingkungan hidup provinsi Jawa Timur dan/atau bupati/walikota di provinsi Jawa Timur, Komisi Penilai Amdal kabupaten/kota, dan/atau kepala instansi lingkungan hidup Kabupaten/Kota di provinsi Jawa Timur untuk baku mutu udara ambien parameter debu/TSP harus menggunakan baku mutu udara ambien parameter debu/tsp PPRI Nomor 41 Tahun 1999 sebagai acuan.

Sebaiknya gubernur Jawa Timur merubah angka baku mutu parameter debu/TSP udara ambien pada Peraturan Gubernur Jawa Timur Nomor 10 Tahun 2009 disesuaikan dengan standar baku mutu udara ambien nasional yang telah diatur dalam Peraturan Pemerintah Republik Indonesia Nomor 41 Tahun 1999 tentang Pengendalian Pencemaran Udara.

\section{E. DAFTAR BACAAN Buku-buku}


Amrah Muslimin, Aspek-aspek Hukum Otonomi Daerah, Alumni, Bandung, 1986.

Christine S.T. Kansil, Pengantar Ilmu Hukum Jilid I, Cetakan Sebelas, Balai Pustaka, Jakarta, 2000.

E. Utrecht, Pengantar Hukum Administrasi Negara Indonesia, Cet 4, Fakultas Hukum dan Pengetahuan Masyarakat Universitas Negeri Pajajaran, Bandung, 1960.

Helmi, Hukum Perizinan Lingkungan Hidup, Cetakan Pertama, Sinar Grafika, Jakarta, 2012.

Moestikahadi Soedomo, Pencemaran Udara (Kumpulan Karya Ilmiah), ITB, Bandung, 2001.

Ni'matul Huda, Hukum Tata Negara Indonesia, PT RajaGrafindo Persada, Jakarta, 2005.

Philipus M. Hadjon, "Pengertianpengertian Dasar tentang Tindak Pemerintahan (Bestuurshandelingen), Djumali, Surabaya, 1985.

Sukardi, Pengawasan Dan Pembatalan Peraturan Daerah, Cetakan Pertama, Genta Publishing, Yogyakarta, 2016.

Suparto Wijoyo, Refleksi Mata Rantai pengaturan Hukum Pengelolaan Lingkungan Secara Terpadu (Studi Kasus Pencemaran Udara), Cet. 1, Airlangga University Press, Surabaya, 2005.

Umar Said Sugiarto, Pengantar Hukum Indonesia, Cetakan
Pertama, Sinar Grafika, Jakarta, 2013.

Yunus Wahid, Pengantar Hukum Lingkungan, Edisi Kedua, Cet 1, Kencana, Jakarta, 2018.

Peraturan Perundang-undangan

Undang-Undang Dasar Negara Republik Indonesia Tahun 1945.

Undang-Undang Nomor 32 Tahun 2009 tentang Perlindungan dan Pengelolaan Lingkungan Hidup

Pengertian udara ambien menurut Pasal 1 ayat (4) Peraturan Pemerintah Republik Indonesia Nomor 41 Tahun 1999 tentang Pengendalian Pencemaran Udara,

Peraturan Pemerintah Nomor 27 Tahun 2012 tentang Izin Lingkungan.

Undang-undang Nomor 23 Tahun 2014 tentang Pemerintahan Daerah.

Undang-undang Nomor 10 Tahun 2004 tentang Pembentukan Peraturan Perundangundangan.

Peraturan Gubernur Jawa Timur Nomor 10 Tahun 2009 tentang Baku Mutu Udara Ambien dan Emisi Sumber Tidak Bergerak.

\section{Jurnal-jurnal}

Minolah, Tinjauan Yuridis Terhadap PembatalanPeraturan Daerah provinsi Di Indonesia, Vol. 8, No. 1, Fakultas Hukum, Universitas Islam Bandung, Bandung, 2011. 